\title{
Smoking Habits among Senior High School Students and Related Factors
}

AKIRA SHIBATA, KATSUHIRO FUKUDA AND TOMIO HIROHATA*

\author{
Department of Public Health, Kurume University School of Medicine, Kurume, 830 \\ and ${ }^{*}$ Department of Public Health, Faculty of Medicine, Kyushu University \\ Maidashi, Fukuoka, 810 Japan
}

\author{
Received for Publication April 16, 1990
}

\begin{abstract}
Summary: The present study was conducted to provide baseline data for an anti-smoking educational program. Nineteen public senior high schools in a prefecture in Kyushu, Japan, participated in the study. In July 1982, unsigned self-administered questionnaires on smoking habits were answered by 4689 students - 3088 males and 1601 females - during a homeroom under the supervision of their class teacher. The proportions of students who admitted that they had smoked cigarettes were $45.9 \%$ for males and $18.2 \%$ for females at the ordinary schools, and $78.1 \%$ for males at vocational schools. Eleven to twenty percent of male students had already smoked cigarettes in primary school. More male students in vocational schools had smoked than either male or female students in ordinary schools. Over $40 \%$ of vocational school students were regular smokers, in contrast to $11.8 \%$ for males and $3.4 \%$ for females at ordinary schools. It was also noted that the younger the students, the earlier the age at which they had smoked their first cigarette. The incidence of smoking at the primary school age appeared to be correlated with the incidence of smoking by a family member and at high school age with the incidence of smoking by a friend. Spending money and a friend who smoked were strongly associated with current smoking status of high school students, while parental smoking had a weak association. These results suggest the need for antismoking education beginning in a lower grade in primary school.
\end{abstract}

Key words: senior high school student-smoking habits - setting for first cigarette - smoking related factors

\section{Introduction}

Cigarette smoking has been demonstrated to be an important risk factor for malignant neoplasms in the respiratory system and for coronary heart disease. Hammond (1964) and Doll et al. (1976) revealed a close association between cigarette smoking and lung cancer from large-scale epidemiologic studies. The risk of lung cancer among ex-smokers after stopping for more than 10 years is reduced to the level of non-smokers and, therefore, the importance of cessation of cigarette smoking has been pointed out. However, it is difficult for habitual smokers to stop smoking. Many measures to stop smoking have been tested, but none have produced very satisfactory results in the long term.

From the view-point of the primary prevention of smoking related diseases,

Reprint requests to: Akira Shibata, Department of Public Health, Kurume University School of Medicine, 67 Asahi-machi, Kurume, Fukuoka, 830 
preventive measures not only have to stop smokers from smoking but also prevent non-smokers from beginning to smoke. Since smoking among young people seems to have many harmful effects on their health, anti-smoking educational programs should urgently be developed and introduced at an early age. Denson et al. (1981), Coe et al. (1982), Jason et al. (1982), and Telch et al. (1982) have introduced smoking prevention programs into schools and reported successful results. This type of intervention study is rare in Japan. Fukuda et al. (1976a, 1976b, 1977) carried out an anti-smoking program for senior high school students and followed them for two years, but they failed to obtain satisfactory results.

To design intervention programs effectively, it is very important to know the prevalence and distribution of smokers among young people and also the setting of their first cigarette smoking experience. A preliminary report on the first cigarette smoking experiences of public high school students has already been published (Siramizu et al. 1986). The present report was aimed to examine these data in more detail and to evaluate some environmental factors related to smoking.

\section{Methods}

Nineteen schools (about 20\% of all public senior high schools in a prefecture in Kyushu, Japan) were sampled, and further, two classes were selected from each grade (grades 1 to 3 correspond approximately to the ages of 16 to 18 years) in each school. These selected public high schools included 15 ordinary schools and 4 vocational schools. All of the ordinary schools were coeducational, and the vocational schools consisted only of male students. The study subjects were all the students enrolled in the 114 clas- ses selected.

In July 1982, unsigned self-administered questionnaires were distributed to the students at the time of a homeroom by their class teachers. It was announced to the students that any information obtained by the questionnaire was to be confidential, and the students were asked to fill out the forms. After 20 minutes, the class teachers collected the questionnaires.

On the day of administration of the questionnaire, the total number of students enrolled in the selected classes were 3226 males and 1660 females. One-hundred-twelve male students and 42 female students were absent on that day and 99.5\% (4710) of all remaining 4732 students responded to the questionnaire. Twenty one of 4710 questionnaires were excluded from the analyses, eight with contradictory answers, one lacking information about smoking habits and twelve lacking identification of sex. Finally, 4689 students, 3088 males and 1601 females, were included in the analyses.

Students were classified into three categories according to their smoking habits: non-smoker, who had never smoked before the survey; ex-smoker, who had smoked at least one cigarette at some time in the past and had stopped smoking; and regular smoker, who was smoking regularly at the time of the present survey. Regular smokers and ex-smokers were examined further to describe their first smoking experience: the age and the reason for beginning smoking, the source of their first cigarette, and the place where they smoked their first cigarette. Regular smokers and ex-smokers were also analyzed as to the age at which they started smoking regularly and the reason they stopped smoking, respectively. In addition to these analyses, the relationship between current smoking status and possible relating factors, i.e. spending money, smoking habits of parents and 
friends were assessed by odds ratios with test-based confidence intervals and tests for trend of odds ratios (Breslow and Day, 1980).

\section{Results}

\section{Prevalence of smoking}

Table 1 shows the smoking habits of senior high school students for each type of school, sex and grade. The proportion of students who had smoked was $45.9 \%$ for males and $18.2 \%$ for females at ordinary schools, and $78.1 \%$ for male students at vocational schools. Four-fifths of vocational school students had smoked at least one cigarette. At ordinary schools, $11.8 \%$ of the male students and $3.4 \%$ of the female students were regular smokers. In contrast, $42.6 \%$ of vocational school students were regular smokers.

The cumulative prevalence rates for the times when cigarette smoking began for each cohort (or grade) of male students are shown in Fig. 1 by the type of

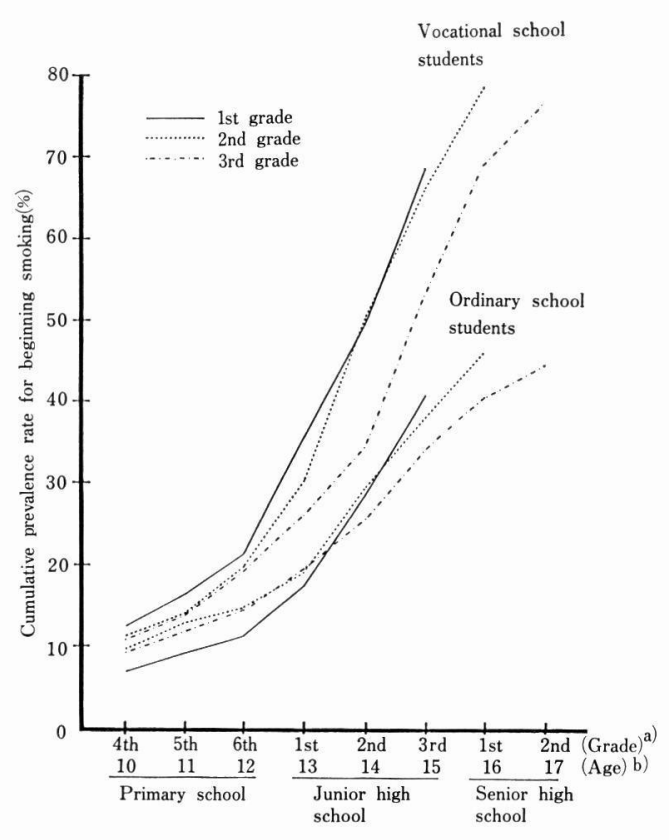

Fig. 1. Cumulative prevalence rate for beginning smoking among male students by type of school and grade.

a) Grade when subjects smoked their first cigarettes.

b) Corresponding approximate age.

TABLE 1

Prevalence of smoking among senior high school students according to the type of school, sex and grade

\begin{tabular}{|c|c|c|c|c|c|c|c|c|c|}
\hline \multirow{3}{*}{$\begin{array}{l}\text { Type of } \\
\text { school }\end{array}$} & \multirow{3}{*}{ Sex } & \multirow{3}{*}{ Grade } & \multicolumn{6}{|c|}{ Smoking habit } & \multirow{3}{*}{ Total } \\
\hline & & & \multicolumn{2}{|c|}{ Non-smoker } & \multicolumn{2}{|c|}{ Ex-smoker } & \multicolumn{2}{|c|}{ Smoker } & \\
\hline & & & No. & $\%$ & No. & $\%$ & No. & $\%$ & \\
\hline \multirow{8}{*}{$\begin{array}{l}\text { Ordinary } \\
\text { school }\end{array}$} & \multirow{3}{*}{ Male } & $1 \mathrm{st}$ & 436 & 57.1 & 280 & 36.6 & 48 & 6.3 & 764 \\
\hline & & $2 \mathrm{nd}$ & 385 & 52.0 & 262 & 35.4 & 94 & 12.7 & 741 \\
\hline & & 3 rd & 394 & 53.0 & 225 & 30.3 & 124 & 16.7 & 743 \\
\hline & \multicolumn{2}{|c|}{ Total } & 1215 & 54.0 & 767 & 34.1 & 266 & 11.8 & 2248 \\
\hline & \multirow{3}{*}{ Female } & 1st & 442 & 85.3 & 60 & 11.6 & 16 & 3.1 & 518 \\
\hline & & 2nd & 447 & 79.8 & 93 & 16.6 & 20 & 3.6 & 560 \\
\hline & & $3 \mathrm{rd}$ & 420 & 80.3 & 84 & 16.1 & 19 & 3.6 & 523 \\
\hline & \multicolumn{2}{|c|}{ Total } & 1309 & 81.8 & 237 & 14.8 & 55 & 3.4 & 1601 \\
\hline \multirow{4}{*}{$\begin{array}{l}\text { Vocational } \\
\text { school }\end{array}$} & \multirow{3}{*}{ Male } & 1st & 74 & 24.8 & 119 & 39.9 & 105 & 35.2 & 298 \\
\hline & & 2nd & 54 & 19.3 & 98 & 35.0 & 128 & 45.7 & 280 \\
\hline & & 3 rd & 56 & 21.4 & 81 & 30.9 & 125 & 47.7 & 262 \\
\hline & \multicolumn{2}{|c|}{ Total } & 184 & 21.9 & 298 & 35.5 & 358 & 42.6 & 840 \\
\hline \multicolumn{3}{|l|}{ Total } & 2708 & 57.8 & 1302 & 27.8 & 679 & 14.5 & 4689 \\
\hline
\end{tabular}


school. A younger cohort seemed to have a greater proportion of first time smokers at a younger age than an older cohort. The highest prevalence rates were observed at the junior high school age for every cohort. Among the male students in the ordinary schools, the cumulative rates at the time of entrance to senior high school were $40.7 \%, 38.0 \%$, and $34.4 \%$, for grades 1,2 , and 3 , respectively. The corresponding figures were $68.7 \%, 66.1 \%$, and $53.1 \%$, at the vocational schools. The rates at the time of entrance to junior high school were $11 \%$ to $15 \%$ among ordinary school students and about $20 \%$ among vocational school students, respectively. The differences in the rates between the types of schools were not large. On the other hand, the differences gradually increased after entrance to a junior high school. The cumulative rate for 1st grade students in ordinary schools increased by $29.5 \%$ during the three years from 6 th grade at the primary school to 3rd grade at the junior high school. The increases in the cumulative rate were $23.2 \%$, and $19.8 \%$, for 2nd and 3rd graders in ordinary schools, respectively. The corresponding figures among vocational school students were $47.3 \%, 46.4 \%$ and $34.0 \%$ for 1st, 2nd and 3rd graders, respectively. About one-half of 1st and 2nd grade students at vocational schools had smoked their first cigarette at a junior high school age. It was evident that the increments in the cumulative rates during the junior high school years were higher among vocational school students than ordinary school students.

Figure 2 shows the cumulative rates of regular smokers for each cohort of male students by the type of school. The cumulative rates before entrance to senior high school were $4.9 \%, 5.0 \%$ and $5.9 \%$ for grades 1, 2 and 3 at ordinary schools and $26.1 \%, 22.9 \%$ and $11.6 \%$ at vocational schools, respectively. As was the

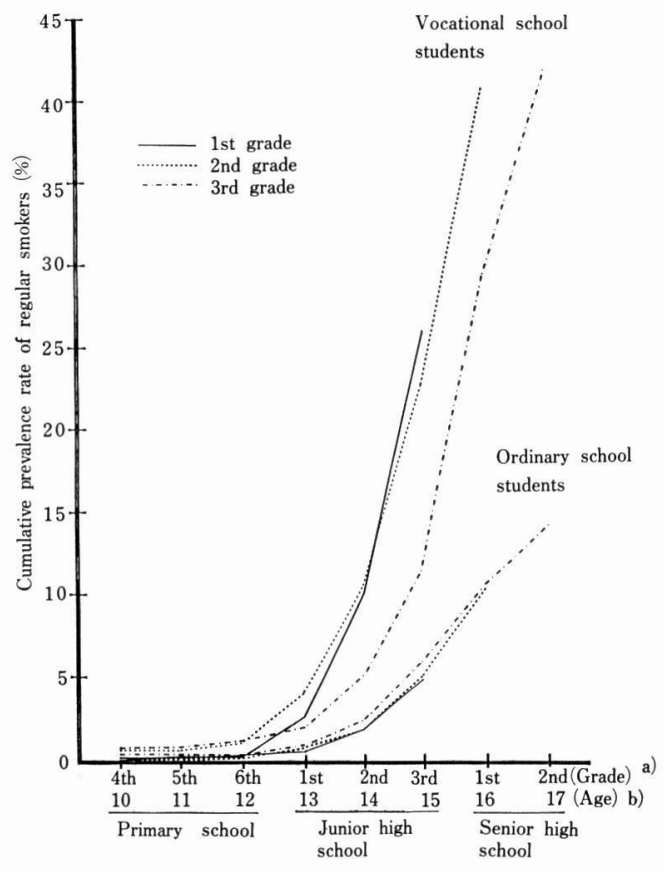

Fig. 2. Cumulative prevalence rate of regular smokers among male students by type of school and grade.

a) Grade when subjects began to smoke regularly.

b) Corresponding approximate age.

case with the initial smoking experience, the younger cohorts seemed to become regular smokers at an earlier age than the older cohorts at vocational schools, but this was not true at ordinary schools. Unlike the first smoking experience, however, the highest cumulative rates for regular smokers were observed at the senior high school ages. Although a similar trend was noticed for female students, detailed analyses were omitted because of the small number of females who were regular smokers or ex-smokers.

II. Setting for the first smoking experience

1) Reasons for smoking the first cigarette

Table 2 shows the reasons why students 
TABLE 2

Reasons for smorking the first cigarette for each type of school, sex and age (\%)

\begin{tabular}{|c|c|c|c|c|c|c|c|c|c|}
\hline \multirow{3}{*}{ Reasons for smoking } & \multicolumn{6}{|c|}{ Ordinary School } & \multirow{2}{*}{\multicolumn{3}{|c|}{$\begin{array}{c}\text { Vocational school } \\
\text { Male }\end{array}$}} \\
\hline & \multicolumn{3}{|c|}{ Male } & \multicolumn{3}{|c|}{ Female } & & & \\
\hline & P.S. & J.H.S. & S.H.S. ${ }^{\text {) }}$ & P.S. & J.H.S. & S.H.S. & P.S. & J.H.S. & S.H.S. \\
\hline Showing off & 3.3 & 1.8 & 1.2 & 0.0 & 0.7 & 0.0 & 3.6 & 0.8 & 1.7 \\
\hline Smoking environment & 14.5 & 20.7 & 22.5 & 10.4 & 14.0 & 17.4 & 16.6 & 21.7 & 29.8 \\
\hline $\begin{array}{l}\text { Suggested by friends } \\
\text { or elders }\end{array}$ & 9.5 & 13.2 & 17.8 & 3.9 & 8.4 & 10.1 & 11.8 & 19.7 & 18.2 \\
\hline Curiosity & 62.2 & 54.1 & 40.8 & 70.1 & 57.3 & 53.6 & 58.6 & 50.3 & 39.7 \\
\hline Stress & 3.0 & 5.7 & 10.7 & 2.6 & 11.9 & 13.0 & 4.7 & 1.9 & 7.4 \\
\hline Other reasons & 6.2 & 3.5 & 4.8 & 6.5 & 5.6 & 2.9 & 4.8 & 2.8 & 2.5 \\
\hline Unknown & 1.3 & 0.9 & 2.4 & 6.5 & 2.1 & 2.9 & 0.0 & 2.8 & 0.8 \\
\hline Total $^{a)}$ & 304 & 545 & 169 & 77 & 143 & 69 & 169 & 360 & 121 \\
\hline
\end{tabular}

a) Fifteen male and 3 female students from ordinary schools and 6 students from vocational schools were excluded from the analysis because the ages when they began smoking were unknown.

b) Abbreviations: P.S. Primary school age at the first smoking

J.H.S. Junior high school age at the first smoking

S.H.S. Senior high school age at the first smoking

smoked their first cigarette by the type of school, sex and age. Regardless of type of school, sex and age of initial smokers, most smoked their first cigarette because of "curiosity". However, the proportion smoking due to "curiosity" consistently decreased with the age of the initial experience; e.g. 62.2\% (primary school) to $40.8 \%$ (senior high school), and $70.1 \%$ to $53.6 \%$, for male and female students at ordinary schools, respectively. The decrease in the proportion in vocational school students was from $58.6 \%$ to $39.7 \%$. In contrast, "smoking environment" and "offers from friends or seniors" became more important.

\section{2) Source of the first cigarette}

The method of obtaining the first cigarette was very different according to age (Table 3). Regardless of the type of school and the sex, the most frequent source of the first cigarette at primary school ages was "family members", often in secret. In contrast, it was "friends" at the senior high school age. Over half of the students who began smoking at the senior high school age obtained their first cigarettes from their friends. Thus, there was a steady reduction in the "family member" proportion and a steady increase in the "friend" proportion with increasing age. Purchasing either from "a cigarette machine" or "a shop" also seemed to increase with the increasing age of the beginning smoker.

\section{3) Places where cigarette smoking begins}

Table 4 shows the locations where cigarette smoking was initiated. A great difference was noted, not only with the ages of the students, but also between the sexes. At the primary school age, 28\% of male students and $40.3 \%$ of female students at ordinary schools smoked their first cigarette at "other places in the house" and not in a "private room", "outdoors" (27.3\%) and a "friend's house" (14.8\%) ranked next for male students. For vocational school students, $36.7 \%$ smoked "outdoors" and this was followed by "other places in the house" (17.8\%) 
TABLE 3

Sources of the first cigarette for the type of school, sex and age when students began smoking (\%)

\begin{tabular}{|c|c|c|c|c|c|c|c|c|c|}
\hline \multirow{3}{*}{$\begin{array}{l}\text { Sources of the first } \\
\text { cigarette }\end{array}$} & \multicolumn{6}{|c|}{ Ordinary School } & \multirow{2}{*}{\multicolumn{3}{|c|}{$\frac{\text { Vocational school }}{\text { Male }}$}} \\
\hline & \multicolumn{3}{|c|}{ Male } & \multicolumn{3}{|c|}{ Female } & & & \\
\hline & P.S. & J.H.S. & S.H.S. ${ }^{\text {b) }}$ & P.S. & J.H.S. & S.H.S. & P.S. & J.H.S. & S.H.S. \\
\hline Cigarette machine & 4.9 & 18.5 & 16.6 & 7.8 & 11.9 & 15.9 & 8.3 & 11.9 & 17.4 \\
\hline Shop & 9.9 & 9.5 & 6.5 & 2.6 & 9.1 & 7.2 & 14.8 & 14.2 & 12.4 \\
\hline Family members & 32.6 & 14.9 & 10.7 & 55.8 & 33.6 & 15.9 & 31.4 & 11.7 & 9.9 \\
\hline Friends & 25.7 & 46.6 & 56.8 & 10.4 & 35.7 & 55.1 & 24.9 & 49.2 & 51.2 \\
\hline Others & 19.1 & 3.7 & 2.4 & 11.7 & 1.4 & 1.4 & 7.1 & 2.2 & 2.5 \\
\hline Unknown & 7.9 & 6.8 & 7.1 & 11.7 & 8.4 & 4.3 & 13.6 & 10.8 & 6.6 \\
\hline Total $^{\text {a) }}$ & 304 & 545 & 169 & 77 & 143 & 69 & 169 & 360 & 121 \\
\hline
\end{tabular}

a) Fifteen male and 3 female students from ordinary schools and 6 students from vocational schools were excluded from the analysis because the ages when they began smoking were unknown.

b) Abbreviations: P.S. Primary school age at the first smoking

J.H.S. Junior high school age at the first smoking

S.H.S. Senior high school age at the first smoking

TABLE 4

Locations of first smoking experiences for each type of school, sex and age (\%)

\begin{tabular}{|c|c|c|c|c|c|c|c|c|c|}
\hline \multirow{3}{*}{$\begin{array}{l}\text { Location of first } \\
\text { smoking experience }\end{array}$} & \multicolumn{6}{|c|}{ Ordinary School } & \multirow{2}{*}{\multicolumn{3}{|c|}{$\begin{array}{c}\text { Vocational school } \\
\text { Male }\end{array}$}} \\
\hline & \multicolumn{3}{|c|}{ Male } & \multicolumn{3}{|c|}{ Female } & & & \\
\hline & P.S. & J.H.S. & S.H.S. ${ }^{\text {) }}$ & P.S. & J.H.S. & S.H.S. & P.S. & J.H.S. & S.H.S. \\
\hline Private room & 9.9 & 20.0 & 24.3 & 15.6 & 34.3 & 29.0 & 15.4 & 20.0 & 24.8 \\
\hline Other place in the house & 28.0 & 10.3 & 10.7 & 40.3 & 14.7 & 17.4 & 17.8 & 7.5 & 4.1 \\
\hline Friend's house & 14.8 & 30.5 & 31.4 & 11.7 & 23.1 & 29.0 & 16.6 & 30.3 & 37.2 \\
\hline Relative's house & 7.9 & 2.4 & 1.8 & 11.7 & 1.4 & 4.3 & 4.1 & 1.9 & 1.7 \\
\hline Restaurant & 1.0 & 2.0 & 4.7 & 2.6 & 1.4 & 4.3 & 0.0 & 0.3 & 0.0 \\
\hline School & 5.9 & 9.9 & 4.7 & 2.6 & 11.2 & 7.2 & 3.6 & 11.1 & 3.3 \\
\hline Outdoors & 27.3 & 22.2 & 16.6 & 6.5 & 9.1 & 4.3 & 36.7 & 25.8 & 24.8 \\
\hline Other reasons & 4.9 & 2.2 & 5.9 & 6.5 & 3.5 & 1.4 & 5.9 & 1.1 & 3.3 \\
\hline Unknown & 0.3 & 0.6 & 0.0 & 2.6 & 1.4 & 2.9 & 0.0 & 1.9 & 0.8 \\
\hline Total $^{\text {a) }}$ & 304 & 545 & 169 & 77 & 143 & 69 & 169 & 360 & 121 \\
\hline
\end{tabular}

a) Fifteen male and 3 female students from ordinary schools and 6 students from vocational schools were excluded from the analysis because the ages when they began smoking were unknown.

b) Abbreviations: P.S. Primary school age at the first smoking

J.H.S. Junior high school age at the first smoking

S.H.S. Senior high school age at the first smoking 
and a "friend's house" (16.6\%). Among the students who first smoked at a junior or senior high school age, a "friend's house" accounted for $30.5 \%$ and $31.4 \%$ of the responses from male students at ordinary schools and $30.3 \%$ and $37.2 \%$ at vocational schools. In contrast, for the females at junior high school ages, a "private room" (34.3\%) was the most frequent place for them to smoke their first cigarette, and this was followed by a "friend's house" (23.1\%). These two responses were also the most frequent $(29.0 \%$ and $29.0 \%$ ) for female students who first smoked at a senior high school age. Students of both sexes seemed to have an increased tendency to smoke their first cigarettes with their friends, as their age increased.

III. Reasons for giving up smoking (multiple answers)

Table 5 shows the reasons for giving up smoking. Ex-smokers most frequently thought cigarette smoking was "absurd".
Three reasons, i. e. "unsavory", "absurd", and "harmful to health" accounted for $80 \%$ to $90 \%$ of the responses, regardless of the age at which they began to smoke. Only $3 \%$ to $12 \%$ of ex-smokers stopped smoking due to pressure, such as "prohibition by law" or "reproof" by their parents or teachers. It was noted that most ex-smokers had stopped smoking of their own free will.

\section{Factors related to smoking}

\section{1) Spending money}

Table 6 shows the strength of the association between spending money per month and current smoking status in terms of the odds ratio with a $95 \%$ confidence interval and the trend of odds ratios by type of school and sex. Chisquare values with one degree of freedom indicated highly significant linear trends or dose-response relationships of odds ratios for both sexes. These results indicated that there was a great effect of

TABLE 5

Reasons for giving up smoking for each type of school, sex and age (multiple answers, \%)

\begin{tabular}{|c|c|c|c|c|c|c|c|c|c|}
\hline \multirow{3}{*}{$\begin{array}{l}\text { Reasons for giving } \\
\text { up smoking }\end{array}$} & \multicolumn{6}{|c|}{ Ordinary School } & \multirow{2}{*}{\multicolumn{3}{|c|}{$\frac{\text { Vocational school }}{\text { Male }}$}} \\
\hline & \multicolumn{3}{|c|}{ Male } & \multicolumn{3}{|c|}{ Female } & & & \\
\hline & P.S. & J.H.S. & S.H.S. ${ }^{b)}$ & P.S. & J.H.S. & S.H.S. & P.S. & J.H.S. & S.H.S. \\
\hline Prohibition by law & 1.6 & 0.8 & 0.0 & 0.0 & 1.8 & 4.9 & 3.4 & 1.3 & 5.9 \\
\hline Reproof & 1.2 & 4.6 & 2.6 & 3.2 & 1.8 & 6.6 & 6.9 & 7.0 & 3.9 \\
\hline Unsavory & 28.0 & 14.2 & 10.3 & 40.3 & 18.9 & 24.6 & 24.1 & 10.8 & 7.8 \\
\hline Absurd & 25.9 & 39.5 & 40.5 & 37.1 & 53.2 & 36.1 & 37.9 & 32.9 & 39.2 \\
\hline Harmful to health & 23.5 & 32.4 & 36.2 & 11.3 & 16.2 & 16.4 & 27.6 & 41.1 & 37.3 \\
\hline Lack of money & 2.1 & 1.3 & 2.6 & 0.0 & 0.9 & 0.0 & 3.4 & 0.0 & 2.0 \\
\hline Other reasons & 16.5 & 8.4 & 10.3 & 11.3 & 11.7 & 13.1 & 6.9 & 8.2 & 3.9 \\
\hline Unknown & 2.9 & 1.5 & 1.7 & 1.6 & 1.8 & 3.3 & 2.3 & 2.5 & 2.0 \\
\hline Total $^{\text {a) }}$ & 243 & 395 & 116 & 62 & 111 & 61 & 87 & 158 & 51 \\
\hline
\end{tabular}

a) Thirteen male and 3 female students from ordinary schools and 2 students from vocational schools who were ex-smokers were excluded from the analysis because the ages when they began smorking were unknown.

b) Abbreviations: P.S. Primary school age at the first smoking

J.H.S. Junior high school age at the first smoking

S.H.S. Senior high school age at the first smoking 
TABLE 6

Odds ratio of becoming a smoker for spending money per month, type of school and sex

\begin{tabular}{|c|c|c|c|c|c|c|c|c|c|}
\hline \multicolumn{3}{|c|}{ Spending money (yen/month) } & & $<3000$ & -5000 & -10000 & $10000 \leqq$ & Unknown & Total \\
\hline \multirow{10}{*}{$\begin{array}{l}\text { Ordinary } \\
\text { School }\end{array}$} & \multirow{5}{*}{ Male } & \multirow{5}{*}{$\begin{array}{l}\text { Non-smoker } \\
\text { Smoker }\end{array}$} & $(\%)$ & $422(34.7)$ & $660(54.3)$ & $88(7.2)$ & $27(2.2)$ & $18(1.5)$ & 1215 \\
\hline & & & $(\%)$ & $35(13.2)$ & $139(52.3)$ & $70(26.3)$ & $21(7.9)$ & $1(0.4)$ & 266 \\
\hline & & & O. R. ${ }^{\text {a) }}$ & 1.0 & 2.5 & 9.6 & 9.4 & & \\
\hline & & & C.I. ${ }^{\text {b) }}$ & - & $1.7-3.7$ & $6.3-14.6$ & $5.3-16.7$ & & \\
\hline & & & \multicolumn{7}{|c|}{ Test for trend: $\chi^{2}=111.0^{*}$} \\
\hline & \multirow{5}{*}{ Female } & \multirow{5}{*}{$\begin{array}{l}\text { Non-smoker } \\
\text { Smoker }\end{array}$} & $(\%)$ & $445(34.0)$ & $739(56.5)$ & $97(7.4)$ & $15(1.1)$ & $13(1.0)$ & 1309 \\
\hline & & & $(\%)$ & $6(10.9)$ & $27(49.1)$ & $12(21.8)$ & $10(18.2)$ & $0(0.0)$ & 55 \\
\hline & & & O.R. & 1.0 & 2.7 & 9.2 & 49.4 & & \\
\hline & & & C.I. & - & $1.2-6.4$ & $3.9-21.4$ & $|23.8-102.9|$ & & \\
\hline & & & \multicolumn{7}{|c|}{ Test for trend: $\chi^{2}=59.9^{*}$} \\
\hline \multirow{4}{*}{$\begin{array}{l}\text { Vocational } \\
\text { School }\end{array}$} & \multirow{4}{*}{ Male } & Non-smoker & $(\%)$ & $75(40.8)$ & $80(43.5)$ & $18(9.8)$ & $9(4.9)$ & $2(1.1)$ & 184 \\
\hline & & \multirow[t]{3}{*}{ Smoker } & $(\%)$ & $82(22.9)$ & $162(45.3)$ & $59(16.5)$ & $52(14.5)$ & $3(0.8)$ & 358 \\
\hline & & & O. R. & 1.0 & 1.9 & 3.0 & 5.3 & & \\
\hline & & & C.I. & - & $1.2-2.8$ & $1.6-5.5$ & $2.6-10.9$ & & \\
\hline
\end{tabular}

Test for trend: $\chi^{2}=26.1^{*}$

a) Odds ratio relative to first category $(<3000)$.

b) $95 \%$ test-based confidence interval.

* $\mathrm{P}<0.01$. (One degree of freedom)

TABLE 7

Odds ratio of becoming a smoker for parental smoking, type of school and sex

\begin{tabular}{|c|c|c|c|c|c|c|c|c|}
\hline \multicolumn{3}{|c|}{ Parental smoking habits } & & $\begin{array}{l}\text { Neither } \\
\text { parent }\end{array}$ & $\begin{array}{l}\text { Father } \\
\text { only }\end{array}$ & $\begin{array}{l}\text { Mother } \\
\text { only }\end{array}$ & Both & Total \\
\hline \multirow{2}{*}{$\begin{array}{l}\text { Ordinary } \\
\text { School }\end{array}$} & Male & $\begin{array}{l}\text { Non-smoker } \\
\text { Smoker }\end{array}$ & $\begin{array}{l}(\%) \\
(\%) \\
\text { O. R. }{ }^{\text {a) }} \\
\text { C.I. }{ }^{\text {b) }}\end{array}$ & $\begin{array}{c}468(41.0) \\
83(34.0) \\
1.0 \\
-\end{array}$ & $\begin{array}{c}619(54.3) \\
138(56.6) \\
1.3 \\
0.9-1.7\end{array}$ & $\begin{array}{c}10(0.9) \\
1(0.4) \\
0.6 \\
0.1-4.4\end{array}$ & $\begin{array}{l}44(3.9) \\
22(9.0) \\
2.8 \\
1.6-4.9\end{array}$ & $\begin{array}{r}1141 \\
244\end{array}$ \\
\hline & Female & $\begin{array}{l}\text { Non-smoker } \\
\text { Smoker }\end{array}$ & $\begin{array}{l}(\%) \\
(\%) \\
\text { O.R. } \\
\text { C.I. }\end{array}$ & $\begin{array}{c}481(38.9) \\
13(25.0) \\
1.0 \\
-\end{array}$ & $\begin{array}{c}683(55.3) \\
31(59.6) \\
1.7 \\
0.9-3.2\end{array}$ & $\begin{array}{c}15(1.2) \\
2(3.8) \\
4.9 \\
1.2-20.6\end{array}$ & $\begin{array}{c}57(4.6) \\
6(11.5) \\
3.9 \\
1.5-10.0\end{array}$ & $\begin{array}{r}1236 \\
52\end{array}$ \\
\hline $\begin{array}{l}\text { Vocational } \\
\text { School }\end{array}$ & Male & $\begin{array}{l}\text { Non-smoker } \\
\text { Smoker }\end{array}$ & $\begin{array}{l}(\%) \\
(\%) \\
\text { O.R. } \\
\text { C.I. }\end{array}$ & $\begin{array}{l}47(30.9) \\
88(27.4) \\
1.0 \\
-\end{array}$ & $\begin{array}{c}92(60.5) \\
188(58.6) \\
1.1 \\
0.7-1.7\end{array}$ & $\begin{array}{l}2(1.3) \\
3(0.9) \\
0.8 \\
0.1-5.0\end{array}$ & $\begin{array}{l}11(7.2) \\
42(13.1) \\
2.0 \\
1.0-4.3\end{array}$ & $\begin{array}{l}152 \\
321\end{array}$ \\
\hline
\end{tabular}

a) Odds ratio relative to first category (Neither parent).

b) $95 \%$ test-based confidence interval. 
TABLE 8

Odds ratio of becoming a smoker for friend's smoking, type of school and sex

\begin{tabular}{|c|c|c|c|c|c|c|c|c|c|}
\hline \multicolumn{3}{|c|}{ Friend's smoking habits } & & \begin{tabular}{|c|} 
Majority \\
of friends \\
never \\
smoke
\end{tabular} & $\begin{array}{c}\text { Quarter } \\
\text { of friends } \\
\text { smoke }\end{array}$ & $\begin{array}{l}\text { Half of } \\
\text { friends } \\
\text { smoke }\end{array}$ & \begin{tabular}{|l} 
Majority \\
of friends \\
smoke
\end{tabular} & Unknown & Total \\
\hline \multirow{4}{*}{$\begin{array}{l}\text { Ordinary } \\
\text { School }\end{array}$} & \multirow[t]{2}{*}{ Male } & \multirow[t]{2}{*}{$\begin{array}{l}\text { Non-smoker } \\
\text { Smoker }\end{array}$} & $\begin{array}{l}(\%) \\
(\%) \\
\text { O. R. }{ }^{a)} \\
\left.\text { C.I. }{ }^{b}\right)\end{array}$ & $\mid \begin{array}{c}824(67.8) \\
8(3.0) \\
1.0 \\
-\end{array}$ & $\mid \begin{array}{c}182(15.0) \\
25(9.4) \\
14.2 \\
7.5-26.7\end{array}$ & $\left|\begin{array}{c}125(10.3) \\
60(22.6) \\
49.4 \\
30.2-81.0\end{array}\right|$ & \begin{tabular}{|c}
$68(5.6)$ \\
$173(65.0)$ \\
262.0 \\
$171.8-399.8$
\end{tabular} & $\begin{array}{r}16(1.3) \\
0(0.0)\end{array}$ & $\begin{array}{r}1215 \\
266\end{array}$ \\
\hline & & & \multicolumn{7}{|c|}{ Test for trend: $\chi 2=626.2^{*}$} \\
\hline & \multirow[t]{2}{*}{ Female } & \multirow[t]{2}{*}{$\begin{array}{l}\text { Non-smoker } \\
\text { Smoker }\end{array}$} & $\begin{array}{l}(\%) \\
(\%) \\
\text { O.R. } \\
\text { C.I. }\end{array}$ & \begin{tabular}{|c|}
$1121(85.6)$ \\
$4(7.3)$ \\
1.0 \\
-
\end{tabular} & \begin{tabular}{|c|}
$95(7.3)$ \\
$3(5.5)$ \\
8.9 \\
$2.5-31.1$
\end{tabular} & \begin{tabular}{|c|}
$68(5.2)$ \\
$16(29.1)$ \\
65.9 \\
$35.0-124.3$
\end{tabular} & $\begin{array}{c}20(1.5) \\
32(58.2) \\
448.4 \\
278.0-723.2\end{array}$ & $\begin{array}{l}5(0.4) \\
0(0.0)\end{array}$ & $\begin{array}{r}1309 \\
55\end{array}$ \\
\hline & & & \multicolumn{7}{|c|}{ Test for trend: $\chi^{2}=429.4^{*}$} \\
\hline \multirow[t]{2}{*}{$\begin{array}{l}\text { Vocational } \\
\text { School }\end{array}$} & \multirow[t]{2}{*}{ Male } & \multirow[t]{2}{*}{$\begin{array}{l}\text { Non-smoker } \\
\text { Smoker }\end{array}$} & $\begin{array}{l}(\%) \\
(\%) \\
\text { O.R. } \\
\text { C.I. }\end{array}$ & $\begin{array}{l}70(38.0) \\
8(2.2) \\
1.0 \\
-\end{array}$ & $\begin{array}{c}38(20.7) \\
10(2.8) \\
2.3 \\
0.9-6.2\end{array}$ & $\mid$\begin{tabular}{c|}
$26(14.1)$ \\
$43(12.0)$ \\
14.5 \\
$6.5-32.0$
\end{tabular} & \begin{tabular}{|c|}
$45(24.5)$ \\
$296(82.7)$ \\
57.6 \\
$32.2-103.0$
\end{tabular} & $\begin{array}{l}5(2.7) \\
1(0.3)\end{array}$ & $\begin{array}{l}184 \\
358\end{array}$ \\
\hline & & & Test & & .1 & & & & \\
\hline
\end{tabular}

a) Odds ratio relative to first category (Majority of friends never smoke).

b) $95 \%$ test-based confidence interval.

$* \mathrm{P}<0.01$. (One degree of freedom)

spending money on current smoking status.

\section{2) Parental smoking}

Table 7 presents the strength of the association between parental smoking and current smoking status of students in terms of the odds ratio with a $95 \%$ confidence interval. The students who had no father and/or no mother at the time of the survey were eliminated from the analysis. Mother who smoked, rather than father who smoked, seemed to have a greater effect on the probability of a daughter smoking. For male students, this odds ratio was found to be insignificant or marginally significant.

\section{3) Friend smoking}

As shown in Table 8, friends who smoke were likely to have a critical ef- fect on smoking among young people. Dose-response relationships of the odds ratios showed a significant association between current smoking status and the proportion with friends who were regular smokers. The odds ratios among vocational school students were lower compared with those among ordinary school students, and the odds ratios were lower among males than among females at ordinary schools. This seems to reflect the greater proportion of smokers at vocational schools than at ordinary schools, and the difference in the proportion of the sexes at the ordinary schools, respectively.

\section{Discussion}

There have been a number of studies 
(Salber et al. 1961; Bewley et al. 1974; Bewley and Bland, 1977; Banks et al. 1978; Beaglehole et al. 1978; Rawbone et al. 1978; Baugh et al. 1982; Ibsen, 1982; Rawbone and Guz, 1982) on smoking habits and related factors among young people in the world. Since the countries, regions, years of the surveys, definitions of smoking habits, types of schools and ages of subjects were very different in these studies, it is rather difficult to compare them with the present study. In the present study there were large differences, not only between sexes, but also between the types of schools, in several aspects of smoking, situations surrounding the first smoking experience and smoking related factors. The proportion of students who have smoked at vocational schools was higher than that at ordinary schools. Especially for males, the proportion of regular smokers at vocational schools was about four times as high as at ordinary schools. When the past history of smoking among vocational school students was taken into account, more had experience with smoking in their early life than did ordinary school students. Smoking among young people generally exerts a negative influence on their life style. Consequently many with smoking experience tend to have poor academic achievement and a higher probability of entering a vocational school. Thus the vocational school students seemed to have a higher tendency to become smokers than ordinary school students.

Students most frequently smoked their first cigarette because of "curiosity", regardless of the age at the time. Japan has an extremely high prevalence rate of adult smokers, when compared to the developed countries in the world. Young people are always exposed, not only to parents and other family members who smoke, but also to other adults who smoke. This probably increases their cu- riosity. A large proportion of beginning smokers at primary school age obtained their first cigarette from a family member, often in secret. Parents or other family members may also play an important role in facilitating smoking by a child. The proportion of "offers from friends or seniors" increased with the age of the first smoking experience, and this trend was observed regardless of the type of school or the sex. Over $50 \%$ of beginning smokers of senior high school age obtained their first cigarettes from their friends. These findings strongly indicate an increasing impact of school friends, as students grow older. In addition, "cigarette machines" were another source of first cigarettes for students.

The first cigarette was frequently smoked at home or outdoors at primary school ages. However, the proportion smoked in "private rooms" or "a friend's house" increased with increasing age of the first smoking experience. Recently, living conditions have improved considerably and the family size has been reduced. Thus more young people have private rooms. This seems to facilitate smoking in "a private room" or "a friend's house".

The odds ratio was calculated to evaluate the association between current smoking status and environmental factors. The present study was cross-sectional, and the time relationship between potential cause and effect was generally obscure. However, the data was analyzed on the assumption that the environmental factors probably reflected the situation in the past to a certain degree, and that these were antecedent factors for current smoking status. An elevated risk of becoming a smoker and a highly significant doseresponse relationship of odds ratios were found for spending money per month and smoking by a friend. These results indicated a strong association between current smoking status among high school 
students, and both spending money and friends who smoked. On the other hand, parental smoking had a weak association with current smoking status.

An anti-smoking educational program should be applicable to both non-smokers and smokers. Considering the difficulty in giving up smoking and the importance of primary prevention, a preventive measure for non-smokers should be of primary importance. Denson et al. (1981), Coe et al. (1982), Jason et al. (1982), and Telch et al. (1982) introduced smoking prevention programs into schools and reported successful results. Although these programs may be efficient for short term prevention, the efficiency for long term prevention is still unknown. The present study indicated that $11 \%$ to $20 \%$ of male students had already smoked their first cigarettes before entrance into a junior high school. This finding indicates that an effective anti-smoking educational program should being in a lower grade at primary school age and that it is rather important to evaluate its long term preventive effect. However, in a society like Japan, where smoking is prevalent among adults, and large proportions of friends or colleagues may be smokers, it is very doubtful that an anti-smoking educational program in early life will have a long term impact on smoking habits. Therefore, it is important to design a well organized smoking prevention program for the early teen-ager, the effect of which should be evaluated over the long term. It is also worthwhile to try to convert the present pro-smoking society to an anti-smoking society, in general. A gradual tax increase, expansion of smokefree public spaces and banning of cigarette vending machines are possible measures for such a social movement.
Acknowledgments: The authors are indebted to the staffs of the prefectural board of education and the directors of the 19 senior high schools for co-operation in the present study, they also wish to thank Miss Mamiko Terada for clerical assistance.

\section{References}

Banks, M. H., Bewley, B. R., Bland, J.M., Dean, J. R. and Pollard, V. (1978). Long-term study of smoking by secondary School-children. Arch. Dis. Child, 53, 12-19.

Baugh, J.G., Hunter, S. M., Webber, L.S. and Berenson, G.S. (1982). Developmental trends of first cigarette smoking experience of children: The Bogalusa heart study. Am. J. Public Health, 72, 1161-1164.

Beaglehole, R., Eyles, E. and Harding, W. (1978). Cigarette smoking habits, attitudes and associated social factors in adolescents. NZ. Med. J. 87, 239-242.

Bewley, B. R., Bland, J. M. and Harris, R. (1974). Factors associated with the starting of cigarette smoking by primary school children. Br. J. Prev. Soc. Med. 28, 37-44.

Bewley, B. R. and Bland, J. M. (1977). Academic performance and social factors related to cigarette smoking by schoolchildren. Br. J. Prev. Soc. Med. 31, 18-24.

Breslow, N.E. and DAy, N.E. (1980). Statistical methods in cancer research. The analysis of case-control studies. IARC Sci. Publ. 32, 122-159.

Coe, R. M., Crouse, E., Cohen, J. D. and Fisher, E. B. (1982). Patterns of change in adolescent smoking behavior and results of a one year follow-up of a smoking prevention program. J. Sch. Health, 52, 348-353.

Denson, R. and Stretch, S. (1981). Prevention of smoking in elementary schools. Can. J. Public Health, 72, 259-263.

Doll, R. and Peto, R. (1976). Mortality in relation to smoking: 20 years' observations on male British doctors. Br. Med. J. 2, 15251536.

Fukuda, K. and Mryake, H. (1976a). [Experimental anti-smoking education and its assessment (first report).] J. Public Health Practice, 40, 270-274.

Fukuda, K. and Miyake, H. (1976b). [Experi- 
mental anti-smoking education and its assessment (second report).] J. Public Health Practice, 40, 337-340.

Fukuda, K. and Miyake, H. (1977). [Experimental anti-smoking education and its assessment (third report).] J. Public Health Practice, 41, 787-791.

Hammond, E. C. (1964). Smoking in relation to mortality and morbidity. Findings in first thirty-four months of follow-up in a prospective study started in 1959 . J. Natl. Cancer Inst. 32, 1161-1188.

IbSEN, K. K. (1982). Smoking habits in 9000 Danish schoolchildren. Acta Paediatr. Scand. 71, 131-134.

Jason, L. A., Mollica, M. and Ferrone, L. (1982). Evaluating an early secondary smoking prevention intervention. Prev. Med. 11, 96-102.

Salber, E. J., Goldman, E., Buka, M. and Welsh,
B. (1961). Smoking habits of high-school students in Newton, Massachusetts. N. Engl. J. Med. 265, 969-974.

Siramizu, M., Hirohata, T., Shibata, A. and FuKUDA, K. (1986). [Smoking habits among high school students and its related factors.] Jpn. J. Sch. Health, 28, 589-596.

Telch, M. J., Killen, J. D., McAlister, A. L., Perry, C. L. and MaccoBy, N. (1982). Long-term follow-up of a pilot project on smoking prevention with adolescents. J. Behav. Med. 5, 1-8.

Rawbone, R.G., Keeling, C. A., Jenkins, A. and Guz, A. (1978). Cigarette smoking among secondary schoolchildren in 1975. J. Epidemiol. Community Health, 32, 53-58.

Rawbone, R.G. and Guz, A. (1982). Cigarette smoking among secondary schoolchildren 19751979. Arch. Dis. Child, 57, 352-358. 